\title{
IMPACT OF BUILDING DESIGN ON ENERGY USAGE OF A PUBLIC LIBRARY
}

\author{
BIN SU \\ Dept of Architecture, Unitec Institute of Technology, Auckland, New Zealand
}

\begin{abstract}
This pilot study is to investigate relationships between Auckland library building design and energy consumption. In Auckland, about sixty public libraries belong to the Auckland Council. A number of Auckland public libraries (32\% of the total number of public libraries in Auckland) are used for this study. A whole year monthly energy consumption data and library building plans of the sample libraries are recorded and supplied by the Auckland Council. This study explores impact of building design factors on energy consumption, which is based on real energy consumption data and building design data of Auckland public libraries. This study converted monthly energy consumption data into annual, winter and summer daily mean energy consumptions per unit volume of library building indoor space $\left(\mathrm{kWh} / \mathrm{m}^{3} /\right.$ day), which is closely related to building design, indoor thermal conditions and building thermal performance under the local climatic conditions. According to relationships between daily mean energy consumptions per unit volume of library building indoor space $\left(\mathrm{kWh} / \mathrm{m}^{3} /\right.$ day $)$ and library building design data, the study presents energy profiles of local libraries and identify major design factors impacting energy consumption of Auckland public libraries.
\end{abstract}

Keywords: Building energy, Building energy efficiency, Building thermal design, Library building design.

\section{INTRODUCTION}

There are a number of previous studies related to impacts of different building design factors on energy efficiency. These design factors are mainly related to building orientation, geometry and envelope. Some studies focus on building orientation, which impacts on solar radiation received (Gupta et al. 2004, Morrissey et al. 2011) and shading (Capeluto 2003). Other studies focus on impacts of building shape (Marks 1997, Mingfang 2002, Aksoy et al. 2006, Adamski 2007) with different orientations (Marks 1997, Florides et al. 2002, Aksoy 2006, Adamski 2007) on energy consumptions under different climates (Depecter et al. 2001). All heat exchanges between indoor space and outdoor space are through the building envelope, which has the greatest impact on building energy consumption (Manioglu et al. 2006, Radhi 2008). Those studies mainly based on mathematical models and computer simulations can be used to compare different building designs for energy efficiency. Some studies used real building energy consumption data and building design data to investigate relationships between them and impact of building design factors on energy efficiency under local climatic conditions (Su 2011, Su 2013). This study explores impact of 
library building design factors on energy consumption, which is based on real energy consumption data and building design data of Auckland public libraries. This study converted monthly energy consumption data into annual, winter and summer daily mean energy consumptions per unit volume of library building indoor space $(\mathrm{kWh} / \mathrm{m} 3 /$ day), which is closely related to building thermal design, indoor thermal conditions and building thermal performance under the local climatic conditions.

\section{ENERGY CONSUMPTION AND BUILDING DESIGN FACTORS}

\subsection{Energy Profiles}

Table 1 shows energy consumption data for the sample libraries. Winter energy consumptions of all sample libraries are more than $25 \%$ of annual energy consumptions during the $25 \%$ time of a year. The mean winter energy consumption is $30.6 \%$ of annual energy consumption in the range between $25.4 \%$ and $41.2 \%$ (see Figure 1). The mean summer energy consumption is $22 \%$ of annual energy consumption in the range between $14.1 \%$ and $26.3 \%$ (see Figure 1). The sample libraries generally use more energy during the winter than summer.

Figure 2 shows 12-months daily mean energy consumptions per unit volume of building indoor space $\left(\mathrm{kWh} / \mathrm{m}^{3} /\right.$ day $)$ of the eighteen sample libraries. During the winter months from June to August or heating months from May to September, daily mean energy consumptions are higher than other months. During the summer, some libraries' daily mean energy consumptions are slightly higher than the months (March, April, October and November) without heating as some libraries use air-conditioning for space cooling during the summer. Figure 3 shows annual, winter and summer daily mean energy consumptions per unit volume of building indoor space $\left(\mathrm{kWh} / \mathrm{m}^{3} /\right.$ day $)$. Some sample libraries' monthly and annual energy consumptions are "outstanding" and significantly higher than the other libraries (see Figure 2, 3). The libraries No. 2, 3, 4, 8,15 are the top five annual energy consumption libraries (see Figure 3). For the top five annual energy consumption libraries, the mean floor area is $707 \mathrm{~m}^{2}$ and significantly smaller than the other libraries $\left(1479 \mathrm{~m}^{2}\right)$. Mean ratios of winter to annual energy consumptions of the top five annual energy consumption libraries and the other libraries are $29.9 \%$ and $30.9 \%$ respectively. Mean ratios of summer to annual energy consumptions of the top five annual energy consumption libraries and the other libraries are $23.3 \%$ and $21.6 \%$ respectively. They are close to mean ratios of winter $(30.6 \%)$ and summer $(22.0 \%)$ of all sample libraries. The mean ratio of building surface to volume of the top five annual energy consumption libraries is 0.45 and much higher than the other libraries (0.32). Annual, winter and summer daily mean energy consumptions per unit volume of building indoor space, and annual, winter and summer energy consumptions per unit area of building floor of the top five annual energy consumption libraries are significantly higher than the other libraries (see Table 2). Small library buildings potentially use more energy than large libraries as smaller library buildings have higher ratios of building surface to volume. A library building with a higher ratio has larger building surface area to lose more heat during the winter and get more heat gain during the summer per unit volume of building indoor space, which is not good for energy efficiency. 
The mean ratio of roof area to building volume of the top five annual energy consumption libraries is 0.28 and higher than the other libraries (0.2). The top five annual energy consumption library buildings are one or two stories buildings and the mean floor area is only $707 \mathrm{~m}^{2}$. The mean ratio of window to wall area of the top five annual energy consumption libraries is 0.39 and higher than the other libraries (0.35). Windows are commonly weak elements for building thermal design. The thermal resistance (R-value) of a single glazed window $\left(0.15 \mathrm{~m}^{2}{ }^{\circ} \mathrm{C} / \mathrm{W}\right.$ for aluminum window frame and $0.19 \mathrm{~m}^{2 \circ} \mathrm{C} / \mathrm{W}$ for wooden or PVC window frame) is very low compared with walls $\left(1.9-2.0 \mathrm{~m}^{2 \circ} \mathrm{C} / \mathrm{W}\right)$ and roofs $\left(2.9-3.5 \mathrm{~m}^{2 \circ} \mathrm{C} / \mathrm{W}\right)$ in accordance with the current standard (SNZ 2009). A library building with a high ratio of building surface to volume potentially increases ratios of roof area to building volume and window to wall area, which is not good for building energy efficiency.

Table 1. Energy consumption data $(\mathrm{kWh})$ of sample libraries.

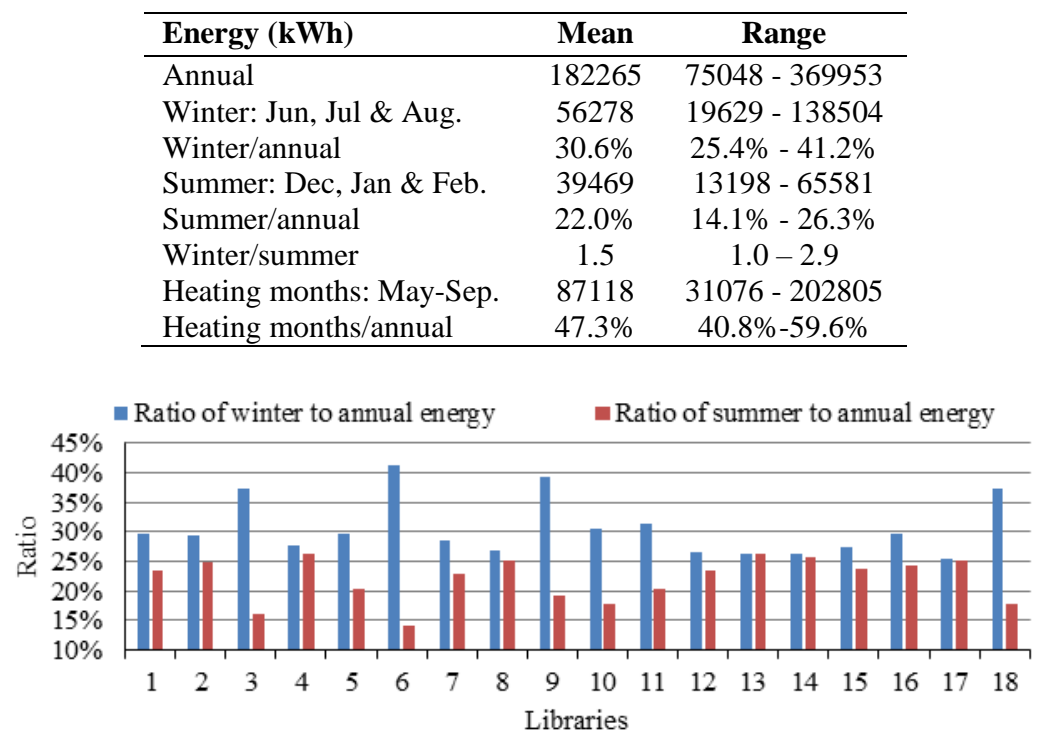

Figure 1. Ratios of winter or summer to annual energy.

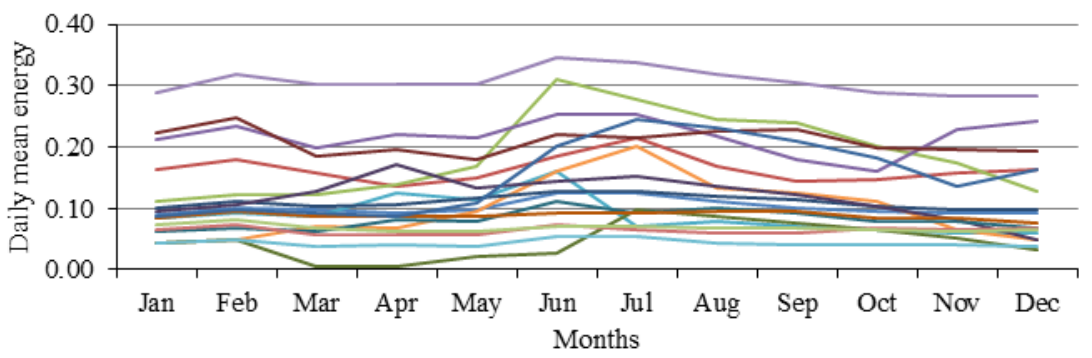

Figure 2. Daily mean energy consumptions $\left(\mathrm{kWh} / \mathrm{m}^{3} /\right.$ day) for 12 months. 


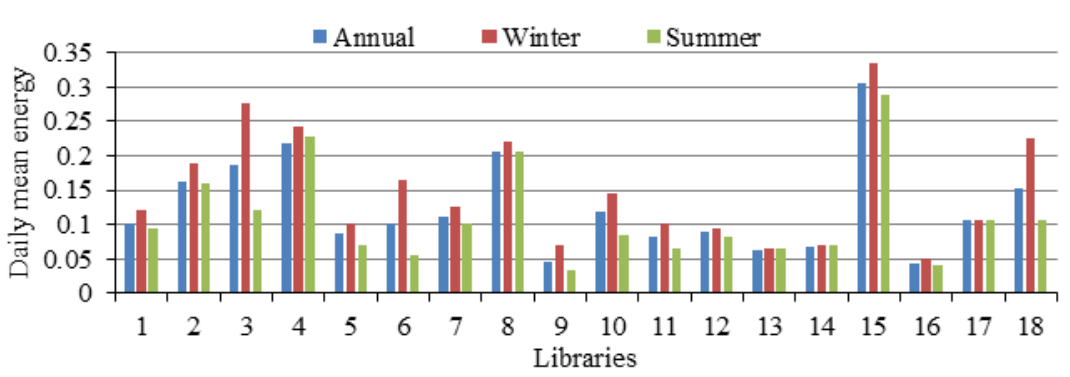

Figure 3. Daily mean energy consumptions $\left(\mathrm{kWh} / \mathrm{m}^{3} / \mathrm{day}\right)$ for annual, winter and summer.

Table 2. Energy consumption data $\left(\mathrm{kWh} / \mathrm{m}^{3} / \mathrm{day}\right)$ of top five energy consumption libraries.

\begin{tabular}{lccc}
\hline Energy & 5 libraries & Other libraries & Difference \\
\hline Annual $\left(\mathrm{kWh} / \mathrm{m}^{3}\right.$ day $)$ & 0.2162 & 0.0897 & 2.4 times \\
Winter $\left(\mathrm{kWh} / \mathrm{m}^{3}\right.$ day $)$ & 0.2525 & 0.1109 & 2.3 times \\
Summer( $\left(\mathrm{kWh} / \mathrm{m}^{3}\right.$ day $)$ & 0.2008 & 0.0752 & 2.7 times \\
Annual $\left(\mathrm{kWh} / \mathrm{m}^{2}\right)$ & 261 & 130 & 2.0 times \\
Winter $\left(\mathrm{kWh} / \mathrm{m}^{2}\right)$ & 77 & 40 & 1.9 times \\
Summer $\left(\mathrm{kWh} / \mathrm{m}^{2}\right)$ & 61 & 28 & 2.2 times \\
\hline
\end{tabular}

\subsection{Building Design Factors}

The ratio of building surface to volume for a multi-story building with the permanent heating should be less than 0.3 for saving space heating energy (Liu 2000). Ratios of building surface to volume of the four libraries No.9, 11, 12, 16 are less than 0.3 . The mean ratio of building surface to volume of the four libraries is 0.24 and much lower than other libraries (0.39). Annual, winter and summer daily mean energy consumptions per unit volume of building indoor space, and annual, winter and summer energy consumptions per unit are of building floor of the four libraries are significantly lower than the other libraries (see Table 3). Mean ratios of winter to annual energy consumptions of the four libraries and the other libraries are $31.7 \%$ and $30.3 \%$. Mean ratios of summer to annual energy consumptions of the four libraries and the other libraries are $21.8 \%$ and $22.1 \%$. They are close to mean ratios of winter $(30.6 \%)$ and summer $(22.0 \%)$ of the all sample libraries. Annual daily mean energy consumptions of the 4 libraries No. 9, 11, 12, 16, are significantly lower than other libraries (see Figure 7,8 ) as their ratios of building surface to volume are much lower than others and less than 03 . Annual daily mean energy consumption of the library No. 16 is the lowest one in all sample libraries and marginally lower than the other three libraries No. 9, No. 11 and No. 12. The library No. 16 has insulation and double-glazed windows. The other three libraries have insulation and signal-glazed windows.

Annual daily mean energy consumption per unit volume of building indoor space $\left(0.2162 \mathrm{kWh} / \mathrm{m}^{3}\right.$ day $)$ of the top five annual energy consumption libraries No. 2 , No. 3 , No, 4, No. 8, No. 15 is 2.4 times of Annual daily mean energy consumption $\left(0.0897 \mathrm{kWh} / \mathrm{m}^{3}\right.$ day $)$ of the other libraries as the mean ratio of building surface to volume $(0.45)$ of the top five annual energy consumption libraries is significantly higher than other libraries (0.32). The top five annual energy consumption libraries have single glazed windows. Without insulation, annual energy consumption of the 
library No.15 is higher than the other four libraries No. 2, No. 3, No. 4, No. 8 . The library No. 8 is built in 2003 and has sufficient insulation in its envelope according to the building code. Annual energy consumption of the library No.8 with sufficient insulation is the third highest annual energy consumption because it has the highest ratio of building surface to volume (0.55) in all sample libraries. According the current standard, a new library will have sufficient insulation in the building envelope and double glazed window. Decreasing ratio of building surface to volume through designs of building size, sharp, geometry, building envelope and elements is crucial to reduce library building energy consumption. Ratio of building surface to volume should be considered as the first level design factor for future library building energy efficiency.

Table 3. Energy and different ratios of building surface to volume.

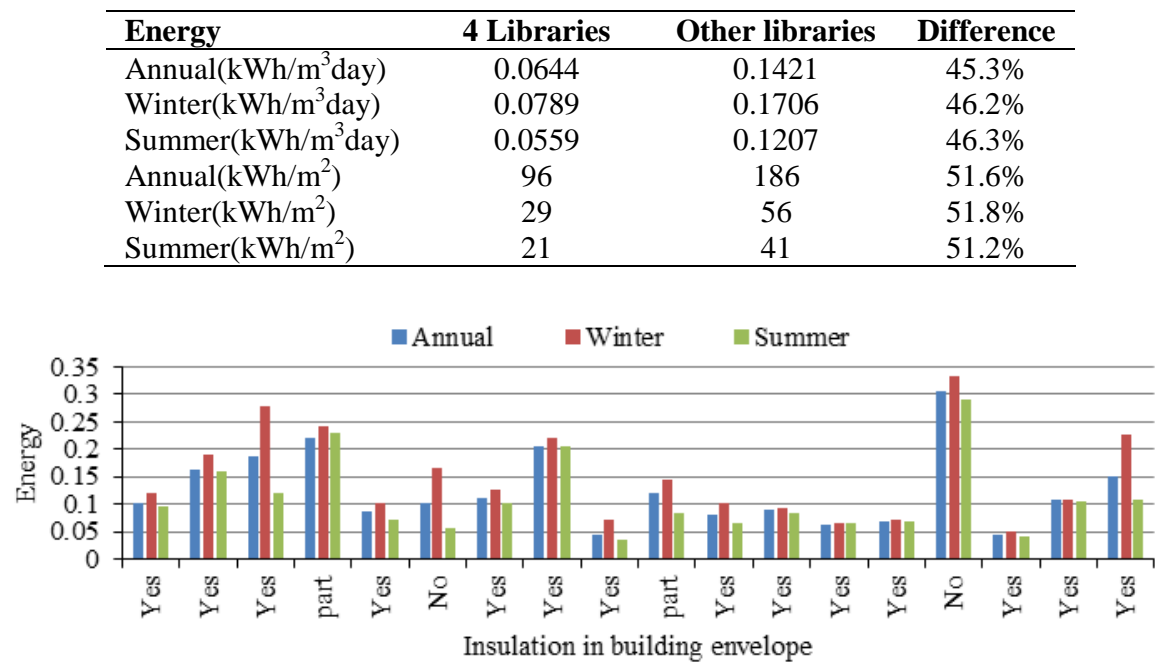

Figure 7. Energy consumptions and insulation.

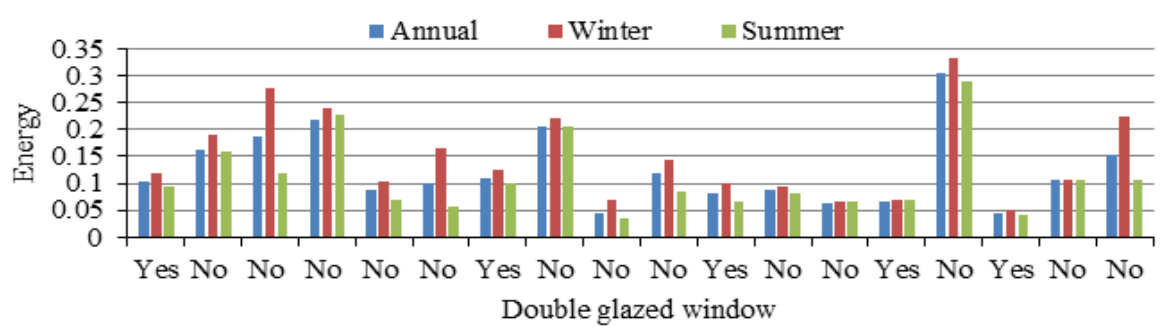

Figure 8. Energy consumptions and double glazed window.

\section{CONCLUSIONS}

Based on energy data of the eighteen sample libraries, the mean winter energy consumption of Auckland public libraries is about $30 \%$ of annual energy consumptions and the mean summer energy consumption of Auckland public libraries is about $22 \%$ of annual energy consumptions during the $25 \%$ time of a year. Auckland public libraries 
use more energy during the winter than other seasons. Auckland library design should more focus on winter thermal performance for building energy efficiency.

Small library buildings use much more annual, winter and summer mean energy consumptions per unit area of building floor, and annual, winter and summer daily mean energy consumptions per unit volume of building indoor space than the large libraries as the smaller library buildings have higher ratios of building surface to volume. The top five annual energy consumption libraries with a mean floor area of $707 \mathrm{~m}^{2}$ and the mean ratio of 0.45 use two times more annual, winter and summer energy than other libraries with the mean floor area of $1479 \mathrm{~m}^{2}$ and a mean ratio of 0.32 .

Four sample libraries' ratios of building surface to volume are less than 0.3. Annual, winter and summer mean energy consumptions of the four libraries with the mean ratio of 0.24 are less than or about $50 \%$ of other libraries with the mean ratio of 0.39 . When the ratio of building surface to volume is very low (less than 0.3 ), double glazed windows can positively impact energy consumption and marginally reduce energy consumption.

\section{References}

Adamski, M., Optimization of the form of a building on an oval base, Building and Environment, 42(4), 1632-1643, 2007.

Aksoy, U. T., and Inalli, M., Impacts of some building passive design parameters on heating demand for a cold region, Building and Environment, 41(12), 1742-1754, December, 2006.

Capeluto, I. G., Energy performance of the self-shading building envelope, Energy and Buildings, 35(3), 327-336, 2003.

Depecter, P., Menezo, C., Virgone, J., and Lepers, S., Design of building shape and energetic consumption, Building and Environment, 36(5), 627-635, June 2001.

Florides, G. A., Tassou, S. A., Kalogirou, S. A., and Wrobel, L. C., Measures used to lower building energy consumption and their cost effectiveness, Applied Energy, 73(3-4), 299328, November-December, 2002.

Gupta, R., and Ralegaonkar, R. B., Estimation of beam radiation for optimal orientation and shape decision of buildings in India, Architectural Journal of Institution of Engineers India, 85, 27-32, 2004.

Liu, J. P, Architectural Physicals, China Construction Industry Publication, Beijing, 2000.

Manioglu, G., and Yilmaz, Z., Economic evaluation of the building envelope and operation period of heating system in terms of thermal comfort, Energy and Buildings, 38 (3), 266272, 2006.

Marks, W., Multicriteria optimisation of shape of energy-saving buildings, Building and Environment, 32(4), 331-339, 1997.

Mingfang, T., Solar control for buildings, Building and Environment, 37(7), 659-664, 2002.

Morrissey, J., Moore, T., and Horne, R.E., Affordable passive solar design in a temperate climate: an experiment in residential building orientation, Renewable Energy, 36(2), 568$577,2011$.

Radhi, H., A systematic methodology for optimising the energy performance of buildings in Bahrain, Energy and Buildings, 40(7), 1297-1303, 2008.

SNZ, New Zealand Standard 4218-2009 Thermal insulation: housing and small buildings, Standards New Zealand, Wellington, New Zealand, 2009.

$\mathrm{Su}, \mathrm{B}$., The impact strength of building passive design on housing energy efficiency, Architectural Science Review, 54(4), 270-276, 2011.

$\mathrm{Su}, \mathrm{B}$., Impacts of Building Design Factors on Auckland School Energy Consumptions, World Academy of Science, Engineering and Technology. International Journal of Civil, Architectural Science and Engineering, 7(12), 265-270, 2013. 